\title{
ELECTROMYOGRAPHIC MEASUREMENT OF FATIGUE
} IN RHEUMATOID ARTHRITIS AND NEUROMUSCULAR DISEASE

\author{
BY \\ J. A. R. LENMAN* AND J. L. POTTER** \\ From the Departments of Neurology and Rheumatology, the Northern General Hospital, Edinburgh, \\ and the Department of Medicine, Queen's College, Dundee
}

Stiffness, particularly "morning stiffness" is a characteristic symptom of active Rheumatoid Disease. An articular component of stiffness has been measured directly in a number of studies (Scott, 1960; Wright and Johns, 1961). Stiffness in muscle is less readily measured and has been given relatively little attention. Stiffness in both muscle and joint increase the load on actively contracting muscle, and can therefore be expected to hasten the onset of muscular fatigue. In an isometric contraction, however, the effect of joint stiffness would presumably be minimal, and the development of fatigue would reflect mainly the muscular component of stiffness. If the rate of development of fatigue could be measured objectively, this should provide information regarding the state of the muscles in rheumatoid disease, as well as in other disorders associated with stiffness or weakness.

This report presents the results of a study of the changes in electrical activity of muscle occurring with fatigue in healthy individuals, patients with rheumatoid disease, and patients with neuromuscular disorders. The changes in the pattern of the myogram occurring with fatigue can be studied in records obtained with surface electrodes. It has been reported that the potentials increase in amplitude and diminish in frequency as fatigue develops (Cobb and Forbes, 1923). Quantitative information about these changes may be derived by graphic or electronic integration of the myogram. It has been shown that the mean voltage of the electromyogram is proportional to the tension of an isometric contraction (Lippold, 1952). The electrical activity

* Present address: Department of Medicine, Queen's College, Dundee.

** Present address: Department of Medicine, New York University Medical Center, 550 First Avenue, New York, 16. with any given tension is increased when muscle has been fatigued by sustained isometric or isotonio contraction (Scherrer, Samson, and Soula, 1954; Edwards and Lippold, 1956; Lenman, 1959b). If a graded series of voluntary contractions, tensiou and voltage have a linear relationship both before and in the state of fatigue, but the slope of the line differs (Edwards and Lippold, 1956; Lenmarye 1959b).

\section{Material and Methods}

The subjects studied were ten healthy individual (Table I, opposite), 23 patients with rheumatoid disease (Table II, overleaf), and 21 patients with muscular weak ness resulting from myopathy or neuropathy (Table II overleaf).

Recordings of tension and electrical activity were obtained from the biceps brachii, and in some instance्s the triceps. The patients with rheumatoid disease were tested in the hours between 5.00 and 7.00 a.m., after period of 24 hours without salicylate medication, \&ी which time morning stiffness was maximal. The other patients and the healthy individuals were tested between 9.00 a.m. and 6.00 p.m.

The subjects were instructed to pull or to push, with the elbow at $90^{\circ}$, against a rigidly mounted lever, so th the contractions were virtually isometric. The mounting of the lever incorporated a pair of strain gauges connected as a Wheatstone bridge energized by a source of constanit alternating voltage. Force applied to the lever resulted in the production of sinusoidal, "out of balance", voltage proportional to the force applied.

The electromyogram was recorded simultaneously frofo surface electrodes placed on the skin over the belly of the appropriate muscle. After amplification, the electrical activity was integrated in a circuit similar to that de cribed by Bates and Cooper (1954). This produced series of pulses at a frequency proportional to the mean voltage of the electromyogram, and these, together wif 
TABLE I

ANALYSIS OF SUCCESSIVE VOLTAGE/TENSION CURVES OBTAINED FROM TEN HEALTHY SUBJECTS

\begin{tabular}{|c|c|c|c|c|c|c|c|c|c|c|}
\hline \multirow{2}{*}{$\begin{array}{l}\text { Sub- } \\
\text { ject } \\
\text { No. }\end{array}$} & \multirow{2}{*}{ Sex } & \multirow{2}{*}{ Muscle } & \multirow{2}{*}{$\begin{array}{c}\text { Maximum } \\
\text { Tension of } \\
\text { Muscle } \\
\text { (lb.) }\end{array}$} & \multicolumn{4}{|c|}{ Regression Coefficients for Successive Voltage/Tension Curves* } & \multirow{2}{*}{$\begin{array}{c}b_{2}-b_{1} \\
\text { Signifi- } \\
\text { cance } \\
\text { of } t\end{array}$} & \multirow{2}{*}{$\begin{array}{c}b_{3}-b_{1} \\
\text { Signifi- } \\
\text { cance } \\
\text { of } t\end{array}$} & \multirow{2}{*}{$\begin{array}{c}b_{4}-b_{1} \\
\text { Signifi- } \\
\text { cance } \\
\text { of } t\end{array}$} \\
\hline & & & & $b_{1}$ & $b_{2}(5 \mathrm{sec})$. & $b_{3}(10 \mathrm{sec})$. & $b_{4}(15 \mathrm{sec})$ & & & \\
\hline 1 & $\mathbf{F}$ & L. Biceps & $36 \cdot 7$ & $r=\begin{array}{l}0.0688(26) \\
0.9672\end{array}$ & $r=\begin{array}{l}0.0691(26) \\
0.957\end{array}$ & $r=0.0692(26)$ & $r=0.0731(26)$ & & & \\
\hline 2 & $\mathbf{F}$ & R. Biceps & $40 \cdot 0$ & $r=0.0681(30)$ & $r=0.0661(30)$ & $r=\begin{array}{l}0.0579(30) \\
0.9168\end{array}$ & $r=0.0648(30)$ & & & \\
\hline 3 & $\mathbf{M}$ & R. Biceps & $52 \cdot 0$ & $r=\begin{array}{l}0.0421(14) \\
0.9790\end{array}$ & $r=\begin{array}{l}0.0453(14) \\
0.9721\end{array}$ & $r=0.0422(14)$ & $r=0.9874(14)$ & & & \\
\hline 4 & $\mathbf{F}$ & R. Biceps & $51 \cdot 4$ & $r=0.9653(16)$ & $r=0.0581(16)$ & $r=0.9615$ & $r=\begin{array}{l}0.0742(16) \\
0.9674\end{array}$ & & & \\
\hline 5 & $\mathbf{F}$ & R. Biceps & $52 \cdot 9$ & $r=0.9729$ & $r=\begin{array}{l}0.0385 \\
0.9757\end{array}$ & $r=0.9481(14)$ & $r=0.9460$ (12) & & & \\
\hline 6 & $\mathbf{M}$ & R. Biceps & $61 \cdot 6$ & $r=0.0228(14)$ & $r=0.9240(14)$ & $r=0.9723$ & $r=0.0305(14)$ & & & 0.01 \\
\hline 7 & $\mathbf{F}$ & L. Biceps & $29 \cdot 9$ & $r=0.0821(18)$ & $r=\begin{array}{l}0.0904(18) \\
0.9041\end{array}$ & $r=0.0998(18)$ & $r=\begin{array}{l}0 \cdot 1089(14) \\
0.8883\end{array}$ & & $0 \cdot 10$ & $0 \cdot 10$ \\
\hline 8 & $\mathbf{F}$ & R. Biceps & $33 \cdot 3$ & $r=\begin{array}{l}0.0522(20) \\
0.9405\end{array}$ & $r=0.9070$ & $r=0.9412$ & $r=\begin{array}{l}0.0501 \\
0.8997\end{array}$ & & & \\
\hline 9 & $\mathbf{F}$ & R. Biceps & $47 \cdot 3$ & $r=0.9558(14)$ & $r=0.0353(14)$ & $r=0.0449(14)$ & $r=0.0589(14)$ & & & 0.01 \\
\hline 10 & $\mathbf{M}$ & R. Triceps & $44 \cdot 4$ & $r=\begin{array}{l}0.0836(8) \\
0.9823\end{array}$ & $r=0.9869$ & $r=0.9495(8)$ & & & & \\
\hline 4 & $\mathbf{F}$ & $\overline{\text { R. Triceps }}$ & $23 \cdot 4$ & $r=0.0658(10)$ & $r=0.0657(10)$ & $r=0.0526(10)$ & $r=0.0660(8)$ & & & \\
\hline 5 & $F$ & $\overline{\text { R. Triceps }}$ & $27 \cdot 2$ & $r=0.8716(10)$ & $r=0.8696$ & $r=\begin{array}{l}0 \cdot 1173(10) \\
0.8244\end{array}$ & $r=\begin{array}{l}0.0846(10) \\
0.5980\end{array}$ & & & \\
\hline 1 & $\mathbf{F}$ & L. Triceps & $22 \cdot 5$ & $r=0.9454$ & $r=0.8729(14)$ & $r=0 \cdot 0 \cdot 1854(14)$ & $r=\begin{array}{l}0.2050(14) \\
0.8571\end{array}$ & & & \\
\hline
\end{tabular}

* No. of observations in brackets.

the sinusoidal output from the dynamometer, were charted on paper by a two-channel pen-writer having a time trace. At the end of each experiment, the circuits were calibrated directly in millivolts and pounds, as described previously (Lenman, 1959a, b).

As in previous studies, the construction of voltage/ tension curves from data obtained in a series of contractions permitted comparison between different subjects of the effects of fatigue despite wide individual differences in maximum strength of contraction (Edwards and Lippold, 1956; Lenman, 1959b). It has been found that the ratio of voltage to tension is consistently greater after a fatiguing contraction than before, but the strength of this contraction is necessarily arbitrary, and difficult to reproduce both in different subjects and also in the same subject on different occasions. As an alternative procedure to some such standard fatiguing contraction, each subject made a graded series of contractions, of at least $30 \mathrm{sec}$. duration, the first weak and the last of maximal effort. From the record of each contraction, the voltage/tension ratio was measured at the initial steady state, and at intervals of 5,10 , and $15 \mathrm{sec}$. thereafter. From these data, voltage/tension curves were derived corresponding with four different periods of progressive fatigue, all within the range of effort from minimum to maximum (Figs 1, 2, and 3, overleaf, pp. 80 and 81).

\section{(1) Healthy Subjects}

\section{Results}

In nine of ten healthy subjects voltage tension curves were constructed as described above, for the biceps muscle, and in three the triceps was also studied. In the tenth subject the triceps alone were studied, and because the contractions were of shorter duration, curves were derived at 5 and 10 sec. only. These ten subjects were adults between 20 and 40 years of age. The results obtained in this group are listed in detail in Table $\mathbf{I}$.

Of the thirteen muscles tested, only two, in both cases the biceps, had a voltage tension curve at the $15 \mathrm{sec}$. epoch significantly steeper than the curve at the initial epoch, and in no instance was the $10 \mathrm{sec}$. curve significantly steeper than the initial (Table IV, below, p. 80).

In every case the coefficient of linear correlation between voltage and tension was high: thus the 
TABLE II

ANALYSIS OF SUCCESSIVE VOLTAGE/TENSION CURVES OBTAINED FROM BICEPS MUSCLE OF 23 PATIENTS WITH RHEUMATOID ARTHRITIS

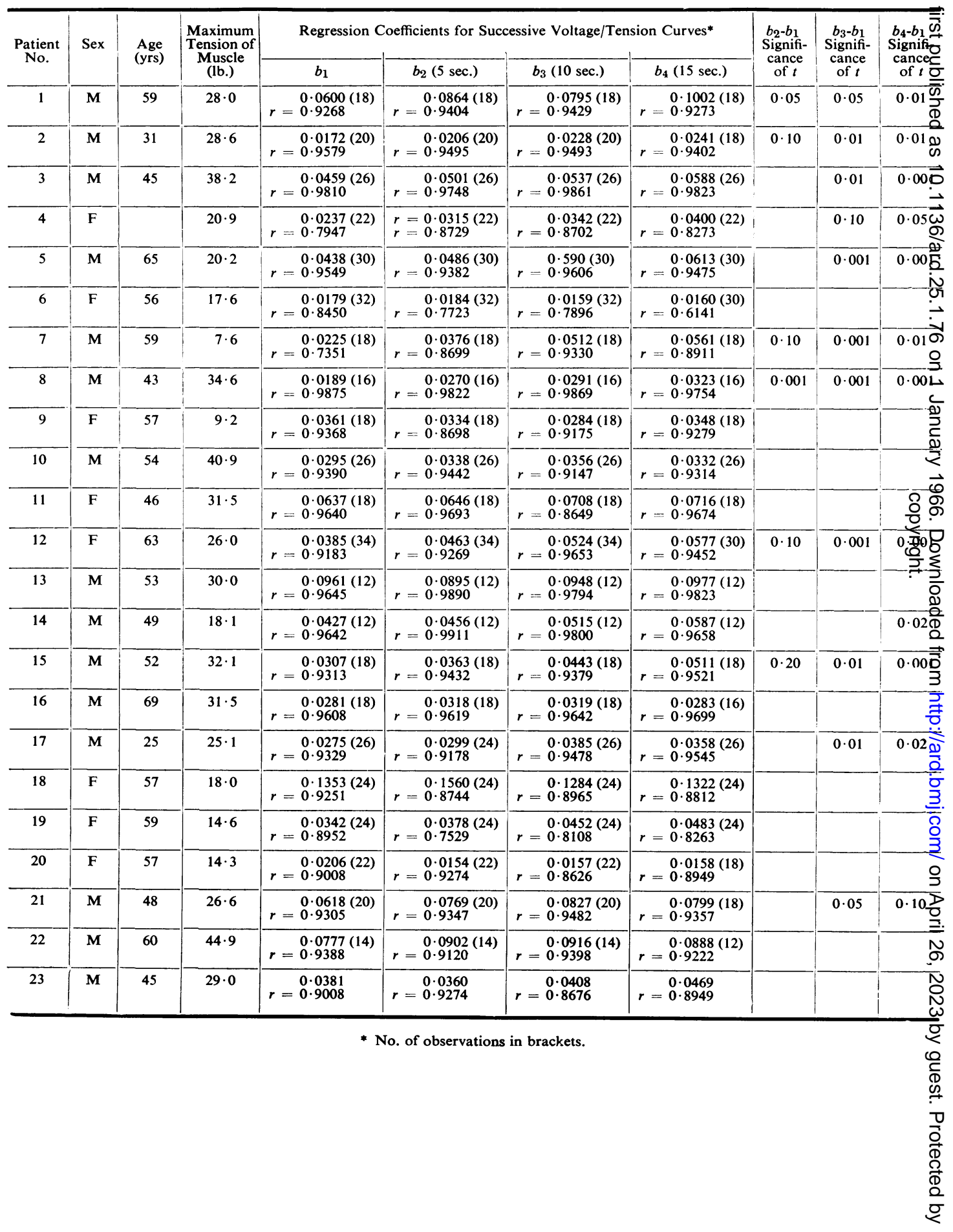


TABLE III

ANALYSIS OF SUCCESSIVE VOLTAGE/TENSION CURVES OBTAINED FROM 21 PATIENTS WITH MUSCULAR (11) AND NEUROLOGICAL (10) DISEASE

\begin{tabular}{|c|c|c|c|c|c|c|c|c|c|c|}
\hline \multirow{2}{*}{$\begin{array}{l}\text { Pat- } \\
\text { ient } \\
\text { No. }\end{array}$} & \multirow{2}{*}{ Sex } & \multirow{2}{*}{ Muscle } & \multirow{2}{*}{ Diagnosis } & \multicolumn{4}{|c|}{ Regression Coefficients for Successive Voltage/Tension Curves* } & \multirow{2}{*}{$\begin{array}{l}b_{2}-b_{1} \\
\text { Signifi- } \\
\text { cance } \\
\text { of } t\end{array}$} & \multirow{2}{*}{$\begin{array}{l}b_{3}-b_{1} \\
\text { Signifi- } \\
\text { cance } \\
\text { of } t\end{array}$} & \multirow{2}{*}{$\begin{array}{c}b_{4}-b_{1} \\
\text { Signifi- } \\
\text { cance } \\
\text { of } t\end{array}$} \\
\hline & & & & $b_{1}$ & $b_{2}(5$ sec.) & $b_{3}(10$ sec.) & $b_{4}(15$ sec. $)$ & & & \\
\hline 1 & $\mathbf{F}$ & R. Biceps & Polymyositis & 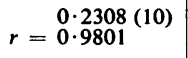 & $r=0.9587(10)$ & $r=0.2484(10)$ & $r=0.2715(10)$ & & & \\
\hline 2 & $\mathbf{M}$ & R. Biceps & $\begin{array}{l}\text { Muscular } \\
\text { dystrophy }\end{array}$ & $r=0.9809(18)$ & $r=0.0453(18)$ & $r=0.0518(18)$ & $r=0.0554(18)$ & 0.05 & 0.001 & $0 \cdot 001$ \\
\hline 3 & $\mathbf{M}$ & L. Biceps & $\begin{array}{l}\text { Muscular } \\
\text { dystrophy }\end{array}$ & $r=0.0661(14)$ & $r=0.9732(14)$ & $r=0.9735$ & $r=\begin{array}{l}0.0786(14) \\
0.9777\end{array}$ & & $0 \cdot 10$ & $0 \cdot 10$ \\
\hline 4 & $\mathbf{M}$ & L. Biceps & $\begin{array}{l}\text { Muscular } \\
\text { dystrophy }\end{array}$ & $r=0.0820(26)$ & $r=0.0965(26)$ & $r=\begin{array}{l}0.1058(26) \\
0.9655\end{array}$ & $r=0.9706(10)$ & $0 \cdot 10$ & 0.01 & 0.01 \\
\hline 5 & $\mathbf{M}$ & L. Biceps & $\begin{array}{l}\text { Muscular } \\
\text { dystrophy }\end{array}$ & $r=0.9312(8)$ & $r=0.8290$ & $r=0.0660(8)$ & $r=\begin{array}{l}0.0260(8) \\
0.5892\end{array}$ & & & \\
\hline 6 & $\mathbf{M}$ & L. Biceps & $\begin{array}{l}\text { Dystrophic } \\
\text { myotonica }\end{array}$ & $r=\begin{array}{l}0.0828(18) \\
0.9734\end{array}$ & $r=0.0847(18)$ & $r=0.9705(18)$ & $r=0 \cdot 1026(16)$ & & 0.01 & 0.05 \\
\hline 7 & $\mathbf{F}$ & L. Biceps & Polymyositis & $r=\begin{array}{l}0.1218(28) \\
0.9510\end{array}$ & $r=0.8996(28)$ & $r=0.1313(28)$ & $r=\begin{array}{l}0.1614(28) \\
0.9427\end{array}$ & & & 0.01 \\
\hline 8 & $\mathbf{F}$ & R. Biceps & $\begin{array}{l}\text { Myasthenia } \\
\text { gravis }\end{array}$ & $r=\begin{array}{l}0.1116(10) \\
0.9838\end{array}$ & $r=\begin{array}{l}0.1695(10) \\
0.9711\end{array}$ & $r=\begin{array}{l}0.1218(10) \\
0.9334\end{array}$ & $r=0.1617(10)$ & 0.02 & & 0.05 \\
\hline 9 & $\mathbf{F}$ & R. Triceps & $\begin{array}{c}\text { Muscular } \\
\text { dystrophy }\end{array}$ & $r=0.8597$ (14) & $r=\begin{array}{l}0.7287(14) \\
0.8528\end{array}$ & $r=\begin{array}{l}0.7359(14) \\
0.8529\end{array}$ & 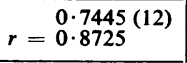 & & & \\
\hline 10 & $\mathbf{M}$ & R. Triceps & $\underset{\text { dystrophy }}{\text { Muscular }}$ & $r=0.9488$ & $r=0.5463(10)$ & $r=\begin{array}{l}0.4501(10) \\
0.9321\end{array}$ & 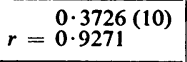 & & & \\
\hline 11 & $\mathbf{F}$ & R. Triceps & $\begin{array}{l}\text { Muscular } \\
\text { dystrophy }\end{array}$ & $r=0.9796$ & $r=0.9684$ & $r=0.9655$ & $r=0.9644(14)$ & 0.05 & $0 \cdot 10$ & 0.05 \\
\hline 12 & $\mathbf{F}$ & L. Biceps & $\begin{array}{c}\text { Motor } \\
\text { neurone } \\
\text { disease }\end{array}$ & $r=0.1231(16)$ & $r=\begin{array}{l}0.1537(16) \\
0.9261\end{array}$ & $r=\begin{array}{l}0.1573(16) \\
0.9290\end{array}$ & $r=\begin{array}{l}0 \cdot 1461(16) \\
0.9572\end{array}$ & & & \\
\hline 13 & $\mathbf{M}$ & L. Biceps & $\begin{array}{c}\text { Motor } \\
\text { neurone } \\
\text { disease }\end{array}$ & $r=0.0664(16)$ & $r=0.0652(16)$ & $r=\begin{array}{l}0.0653(16) \\
0.8289\end{array}$ & $r=\begin{array}{l}0.0875(4) \\
0.9899\end{array}$ & & & \\
\hline 14 & $\mathbf{F}$ & R. Biceps & Syringomyelia & 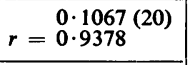 & $\begin{array}{l}0.1298(20) \\
0.8763\end{array}$ & $r=\begin{array}{l}0.1325(20) \\
0.9328\end{array}$ & $r=0 \cdot 8787(10)$ & & & \\
\hline 15 & $\mathbf{F}$ & L. Biceps & $\begin{array}{c}\begin{array}{c}\text { Peripheral } \\
\text { neuritis }\end{array} \\
\end{array}$ & $r=0.9732(22)$ & 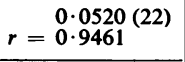 & $r=\begin{array}{l}0.0515(22) \\
0.9574\end{array}$ & $r=0.9496(16)$ & $0 \cdot 10$ & 0.05 & 0.001 \\
\hline 16 & $\mathbf{F}$ & R. Biceps & $\begin{array}{c}\begin{array}{c}\text { Pseudo- } \\
\text { bulbar } \\
\text { palsy }\end{array} \\
\end{array}$ & $r=\begin{array}{l}0.0328(12) \\
0.9478\end{array}$ & $r=\begin{array}{l}0.0383(12) \\
0.9459\end{array}$ & $r=0.0467(12)$ & $r=\begin{array}{l}0.0342(8) \\
0.7454\end{array}$ & & & \\
\hline 17 & $\mathbf{M}$ & R. Biceps & Poliomyelitis & $r=0.8979$ & $r=\begin{array}{l}0.9521(10) \\
0.8641\end{array}$ & $r=0.9274$ & $r=0.8758$ & & & \\
\hline 18 & $\mathbf{F}$ & L. Biceps & Poliomyelitis & $r=\begin{array}{l}0.1050(8) \\
0.9526\end{array}$ & $r=0.9672(8)$ & $r=\begin{array}{l}0.1848(8) \\
0.9730\end{array}$ & $r=0.9632$ & 0.02 & 0.01 & 0.01 \\
\hline 19 & $\mathbf{F}$ & L. Biceps & Poliomyelitis & 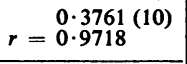 & $r=0.9683$ & $r=0.3501(10)$ & $r=\begin{array}{l}0.3955(4) \\
0.9507\end{array}$ & & & \\
\hline 20 & $\mathbf{M}$ & Biceps & Poliomyelitis & $r=0.6141(12)$ & $r=\begin{array}{l}0 \cdot 3491(12) \\
0 \cdot 7470\end{array}$ & $r=0.2421(12)$ & $r=0.7709$ & & & \\
\hline 21 & $\mathbf{F}$ & L. Triceps & Poliomyelitis & $r=0.9725(14)$ & $r=0.9194$ & $r=0.2453(14)$ & $r=0.2683(14)$ & & & \\
\hline
\end{tabular}

* No. of observations in brackets.

mean correlation coefficient of the 36 regressions calculated from data obtained on the nine biceps muscles was 0.9290 , S.D. 0.0643, and of the fifteen regressions on the four triceps muscles it was $0 \cdot 8847$, S.D. 0.0927.
(2) Patients with Rheumatoid Disease

The results of the tests on the biceps muscles of 23 patients with rheumatoid disease are listed in Table II. In two of these, the voltage tension curve at the 5 sec. epoch was significantly steeper than at the 


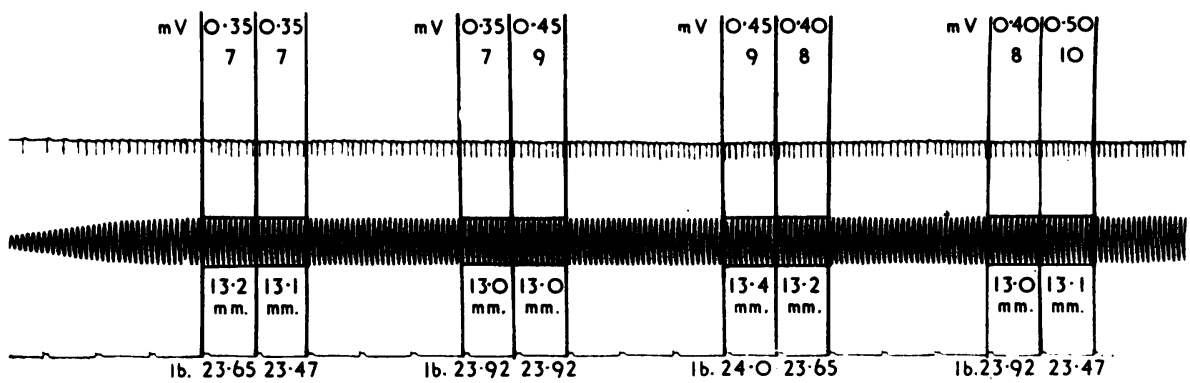

Fig. 1.-Portion of record representing a single contraction of biceps muscle of a rheumatoid patient (Case 2 in Table II). Time scale is 1 sec. Tension is derived from amplitude of sine wave and integrated mean voltage from pulse count.

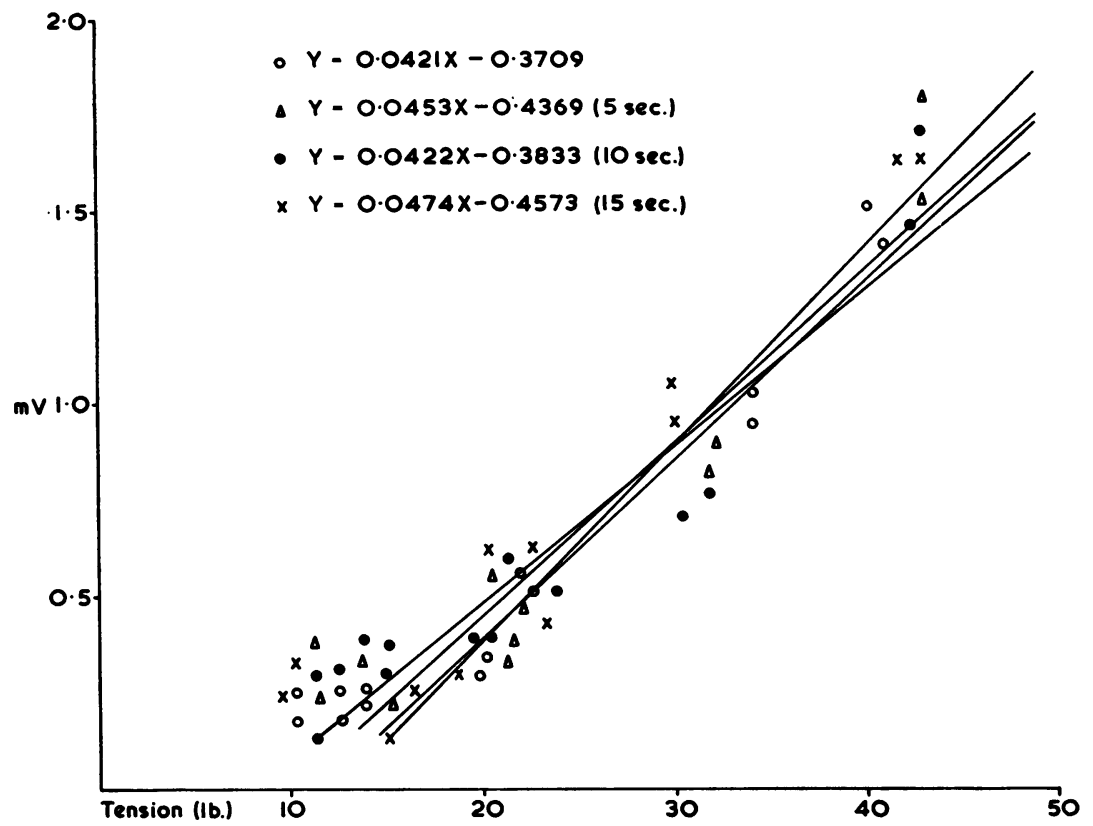

Fig. 2.-Voltage/tension curves obtained from biceps muscle of a healthy subject (No. 3 in Table I). The difference in slope between the four curves is not significant.

TABLE IV

NUMBERS OF SUBJECTS SHOWING ALTERATION IN SLOPE OF SUCCESSIVE VOLTAGE/TENSION CURVES

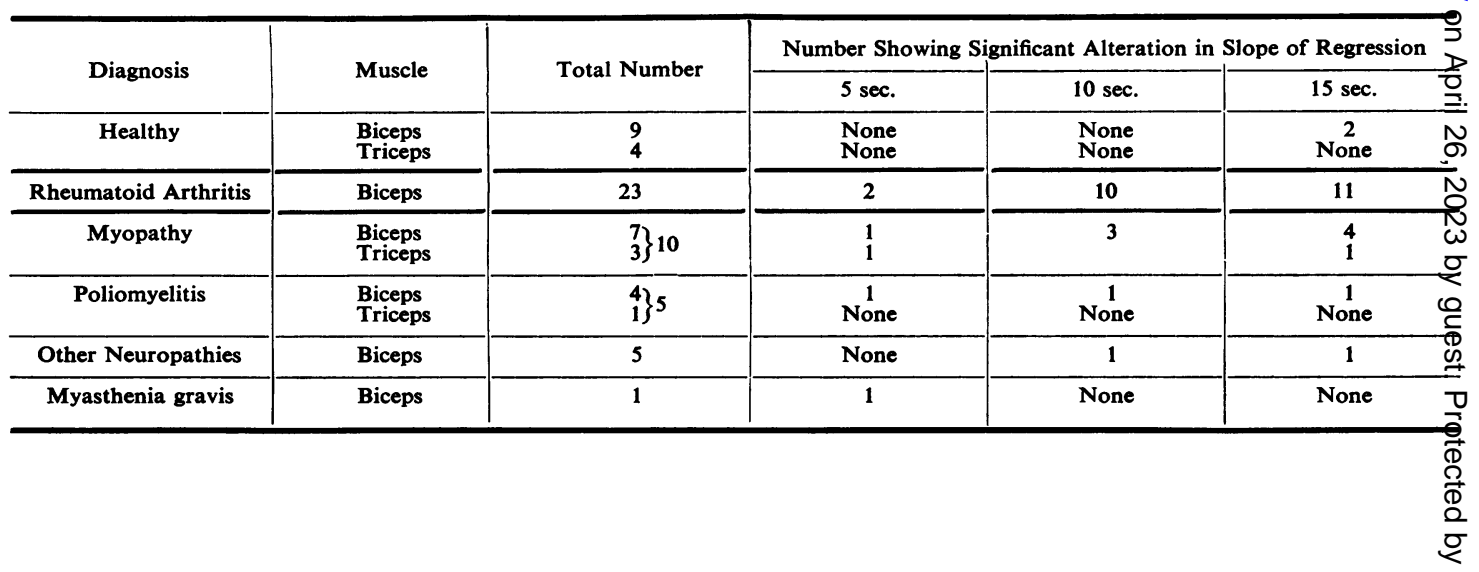




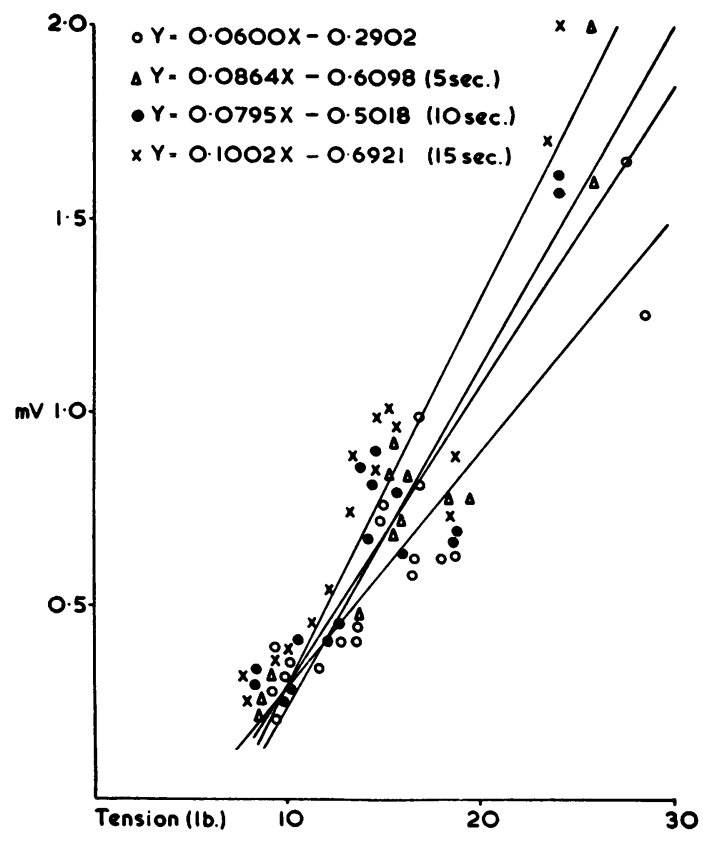

Fig. 3. - Voltage/tension curves obtained from the biceps muscle of a patient with rheumatoid arthritis and morning stiffness (Case 1 in Table II). The curves representing the 5, 10, and 15 second epochs are all significantly steeper than the initial curve. initial epoch. At the 10 sec. epoch, a similar change occurred in ten, and at the 15 sec. epoch, in eleven. Patient 9 (a woman aged 57) on treatment with prednisolone did not complain of morning stiffness, and in her case the slopes of the four curves did not differ significantly one from another. In the differences between the slopes at the initial and $10 \mathrm{sec}$. epochs, the group of rheumatic patients was significantly abnormal ( $\chi^{2}$ with Yates's correction $=3 \cdot 84 ; P=0.05 ;$ Table VIII, p. 82).

The mean coefficient of linear correlation of the 92 regressions calculated from data obtained in the rheumatic group was 0.9210, S.D. 0.0629 (Table VII). The muscles of the rheumatic patients were significantly weaker than those of the healthy subjects. Thus the mean of the maximum tensions produced by the biceps in the rheumatic patients was $26.51 \mathrm{lb}$. (S.D. 8.043), in contrast to a mean of $45.0 \mathrm{lb}$. (S.D. 10.623) in the healthy subjects (Table VI). It was also evident that the contractions of the muscles of patients with rheumatoid disease took an unusually long time to build up to a steady tension. The mean slope of the initial voltage tension regressions of the rheumatic patients was $0 \cdot 0439$ (S.D. 0.0284) and did not differ significantly from that of the healthy subjects which was 0.0536 (S.D. 0. 0194) (Table V).

TABLE V

MEAN VALUES FOR REGRESSION COEFFICIENTS REPRESENTING SLOPE OF INITIAL VOLTAGE/TENSION CURVE IN EACH GROUP STUDIED

\begin{tabular}{|c|c|c|c|c|c|c|c|c|}
\hline \multirow{3}{*}{$\begin{array}{c}\text { No. of Persons } \\
9\end{array}$} & \multirow{2}{*}{\multicolumn{6}{|c|}{ Group }} & \multicolumn{2}{|c|}{ Voltage/Tension Curves for Biceps } \\
\hline & & & & & & & \multirow{2}{*}{$\frac{b \text { for Initial Regression }}{0.0536}$} & \multirow{2}{*}{$\begin{aligned} \text { S.D. } \\
0.0194\end{aligned}$} \\
\hline & Healthy Subjects .. & .. & . & $\ldots$ & $\ldots$ & .. & & \\
\hline 23 & Rheumatoid Arthritis & . & . & . & . & . & 0.0439 & $0 \cdot 0284$ \\
\hline 7 & Myopathy .. & . & . & . & . & . & $0 \cdot 1008$ & 0.0624 \\
\hline 5 & Neuropathy & $\ldots$ & . & $\ldots$ & $\ldots$ & 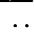 & 0.0744 & 0.0916 \\
\hline 4 & Weakness due to Polio & yeli & .. & $\cdots$ & . & . & $0 \cdot 5589$ & \\
\hline
\end{tabular}

TABLE VI

AVERAGE MAXIMUM VOLUNTARY TENSION FOR THE BICEPS MUSCLE OF 9 HEALTHY SUBJECTS AND 23 PATIENTS WITH RHEUMATOID ARTHRITIS

\begin{tabular}{|c|c|c|c|c|c|c|}
\hline \multirow[t]{2}{*}{ No. of Persons } & \multirow[t]{2}{*}{ Group } & \multirow[b]{2}{*}{ · } & & \multicolumn{3}{|c|}{ Maximum Voluntary Tension of Biceps } \\
\hline & & & & Mean (lb.) & Range (lb.) & S.D. \\
\hline 9 & Healthy Subjects ... & $\ldots$ & $\ldots$ & $45 \cdot 0$ & $29 \cdot 9-61 \cdot 6$ & $10 \cdot 62$ \\
\hline 23 & Rheumatoid Arthritis & .. & $\ldots$ & $26 \cdot 5$ & $7 \cdot 6-44 \cdot 9$ & $8 \cdot 04$ \\
\hline
\end{tabular}


AVERAGE CORRELATIONS COEFFICIENT WITH A STRAIGHT LINE FOR THE REGRESSION EQUATIONS IN EACH GROUP

\begin{tabular}{|c|c|c|c|c|c|c|c|}
\hline No. of Persons & Group & & & & $\begin{array}{l}\text { Number of } \\
\text { Regressions }\end{array}$ & $\begin{array}{c}\text { Mean Correlation } \\
\text { Coefficient }\end{array}$ & S.D. \\
\hline 9 & Healthy Subjects .. & $\cdots$ & . & . & 51 & 0.9290 & 0.0643 \\
\hline 23 & Rheumatoid Arthritis & . & .. & . & 92 & 0.9210 & 0.0629 \\
\hline 10 & Myopathies & $\cdots$ & $\cdots$ & . & 40 & 0.9337 & 0.0732 \\
\hline 5 & Poliomyelitis & $\cdots$ & $\cdots$ & $\cdots$ & 20 & 0.9030 & 0.0726 \\
\hline 5 & Other Neuropathies & $\cdots$ & . & $\cdots$ & 20 & 0.9213 & 0.0548 \\
\hline 1 & Myasthenia gravis & $\cdots$ & . & . & 4 & 0.9616 & \\
\hline 53 & Total & $\ldots$ & . & . & 227 & 0.9241 & 0.0648 \\
\hline
\end{tabular}

TABLE VIII

PROPORTION OF INDIVIDUALS IN EACH GROUP IN WHICH THERE IS A SIGNIFICANT DIFFERENCE BETWEEN THE INITIAL AND THE 10-SEC. REGRESSION COEFFICIENT

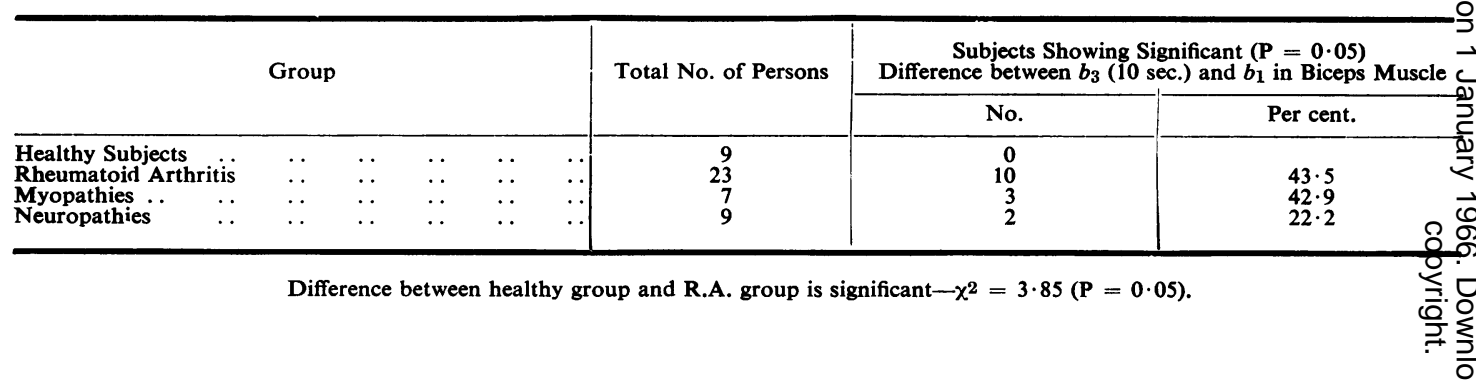

\section{(3) Eleven Patients with Muscular Disorders}

(Table III)

The group included seven patients with muscular dystrophy, two with polymyositis, one with dystrophia myotonica, and one with myasthenia gravis.

In three of the patients with muscular dystrophy the triceps muscle was tested, and in all others the biceps.

Of the seven biceps muscles tested in this group of patients, three showed a significant difference in the slope of the voltage tension curves between the initial and $10 \mathrm{sec}$. epochs (Table IV). The difference between the patients in this group and the healthy subjects was not, however, significant.

Muscle power varied considerably from one patient to another in this group, but two of those with muscular dystrophy (Nos 2 and 11 in Table III), whose $5 \mathrm{sec}$. slopes differed significantly from the initial, had little clinical evidence of weakness in the muscles tested. The one patient with dystrophia myotonica (No. 6) had little weakness of the left biceps, but myotonia was readily demonstrable in this muscle.

The mean coefficient of correlation calculated from the voltage tension data recorded on the patients with muscular dystrophy or polymyositis was 0.9337 (S.D. 0.0723) (Table VII). The meart slope of the initial voltage tension curves was $0 \cdot 1008$ (S.D. 0.0624) in the biceps muscles of the seven patients with myopathy. This slope is considerable $\vec{y}$. steeper than that calculated from the data on the healthy subjects, a finding previously reporte (Lenman, 1959b). From the data on the patien? with myasthenia gravis (No. 8) the voltage tension regression was even steeper $(0 \cdot 1116)$, and it may be relevant that myopathic features were found in the muscles of this patient at autopsy.

\section{(4) Ten Patients with Neuropathic Weakness}

\section{(Table III)}

The young adul) included five (four children and one young adult) with severe muscular weakness of some years' duration following acute poliomyelitis. In addition, there were five adults with muscular weakness resulting from active neuropathy: motor neurone disease (2), syringomyelia (1), bulbar palsy (1), an polyneuritis (1). With the exception of the young adult with post-poliomyelitic weakness, in whom the 
triceps muscle was tested (No. 21), all patients in this group had the tests performed on the biceps muscles.

In only one of the five patients with post-poliomyelitic weakness did the voltage tension curve at the $10 \mathrm{sec}$. epoch differ significantly from the initial curve. The two curves differed significantly in only one of the five patients with neuropathy (Table IV).

The mean coefficient of correlation of the 20 voltage tension regressions in the poliomyelitis patients was 0.9030 (S.D. 0.0726). From the data on the other patients with neuropathic weakness, the coefficient was 0.9213 (S.D. 0.0548) (Table VII).

The mean slope of the voltage tension curves in the poliomyelitis group was $0 \cdot 5589$, and was thus very much steeper than that recorded in the healthy subjects, a finding previously reported (Lenman, 1959b). The mean slope of the regression in the other five patients with neuropathy was 0.0744 (Table V).

\section{Discussion}

Pain and stiffness of the inflamed joints of patients with rheumatoid disease are usually so disabling that it is difficult to evaluate the muscular component of stiffness by clinical examination. Nevertheless, patients with active disease frequently do complain of stiffness "in the muscles", especially when they awaken in the morning. It has been observed that this morning stiffness is accompanied by an impairment of "grip strength" and an increase in the volume of the tissues of the hand (Scott, 1960). Some increase in the resistance of joints to passive movement has also been observed and it is likely that this would accelerate the onset of fatigue during active exercise. In the present study evidence has been presented to show that, in patients with active rheumatoid disease, muscle fatigue also develops with undue rapidity in the course of isometric contraction. It is suggested that this constitutes evidence for an abnormality within muscle itself.

In this report attention has been restricted to possible differences between normal subjects and patients in fatiguability of muscle. While admittedly small numbers of subjects were studied, it appears that a significant proportion of the patients with rheumatoid disease did show a measurably excessive degree of muscular fatiguability at a time when morning stiffness was maximal. Whether this abnormality persists throughout the day and whether it can be influenced by therapy are problems which remain to be investigated.

It is of interest that, of all the subjects investigated, it was those with myopathic disorders who most closely resembled the arthritic patients in terms of muscular fatiguability. Histological evidence of patchy degeneration of muscle fibres, "nodular myositis", has been reported as a feature of rheumatoid disease (Steiner, Fruend, Leichtentritt, and Maun, 1946), and needle electromyography in patients with this disease has shown patterns with an excess of polyphasic motor units resembling those of muscular dystrophy and of polymyositis (Steinberg and Wynn Parry, 1961). In addition, these workers and others have observed discontinuities in the strength/duration curves in rheumatoid disease, indicating partial denervation, perhaps as a consequence of damage to the distal nerve terminals.

In the present study, the patients with rheumatoid disease had a significant degree of muscular weakness, but the mean slope of their voltage tension regressions did not differ significantly from that of the healthy individuals. This finding indicates that in contrast with the weakness of muscular dystrophy, the loss of power is not a result of decreased efficiency of the muscle fibres (Lenman, 1959b), but is more likely to be secondary to stiffness and pain. These factors probably contribute also to the slowness of the build up to steady tension observed in some of the patients with rheumatoid disease. Scott (1960) has suggested that one possible mechanism for the occurrence of morning stiffness may be a change in the elasticity of connective tissue, and it is conceivable that such a change could be reflected by the abnormal fatiguability of muscle observed in these patients.

\section{Summary}

(1) A method is described for the quantitative study of electromyographic changes associated with fatigue in different subjects.

(2) This has been applied to the study of ten healthy subjects, 23 patients with morning stiffness due to rheumatoid arthritis, and 21 patients with myopathy or with various forms of neuropathy.

(3) Electrical changes associated with fatigue are most prominent in the rheumatoid patients, are also present in certain of the myopathic patients, but are inconspicuous in the remaining subjects.

This study was supported by grants from the Scottish Hospitals Endowments Research Trust and the Nuffield Foundation which are gratefully acknowledged. We wish to thank Dr. J. J. R. Duthie, Prof. J. A. Simpson, and Prof. I. G. W. Hill for facilities and for their interest and Mr. J. R. Gray for statistical advice.

\section{REFERENCES}

Bates, J. A. V., and Cooper, J. D. (1954). J. Physiol. (Lond.), 123, $28 \mathrm{p}$.

Cobb, S., and Forbes, A. (1923). Amer. J. Physiol., 65, 234. 
Edwards, R. G., and Lippold, O. C. J. (1956). J. Physiol. (Lond.), $132,677$.

Lenman, J. A. R. (1959a). J. Neurol. Neurosurg. Psychiat., 22, 182. (1959b). Ibid., 22, 306.

Lippold, O. C. J. (1952). J. Physiol. (Lond.), 117, 492.

Scherrer, J., Samson, M., and Soula, C. (1954). J. Physiol. (Paris), 46, 517.

Scott, J. T. (1960). Ann. rheum. Dis., 19, 361.

Steinberg, V. L., and Wynn Parry, C. B. (1961). Brit. med. J., 1, 630.

Steiner, G., Freund, H. A., Leichtentritt, B., and Maun, M. E. (1946). Amer. J. Path., 22, 103.

Wright, V., and Johns, R. J. (1961). Ann. rheum. Dis., $20,36$.

\section{Mesurage électromyographique de la fatigue dans l'arthrite rhumatismale et dans des maladies neuromusculaires}

RÉSUMÉ

1. On décrit une méthode pour l'étude quantitative des altérations électromyographiques associées à la fatigue chez de divers sujets.
2. Cette méthode fut appliquée chez dix individus sains, chez 23 malades souffrant d'enraidissemenश matinal du à l'arthrite rhumatismale et chez 21 malades atteints de myopathie ou de diverses formes neuropathie.

3. Les altérations électriques associées à la fatigue sont le plus accentuées chez les malades rhumatisants elles sont aussi présentes chez certains malades myopathiques, mais peu apparentes chez les autres sujet?

Medida electromiográfica de la fatiga en la artritis reumatoide y enfermedades neuromusculares.

\section{SUMARIO}

1. Se describe un método para estudiar cuantitativamente las alteraciones electromiográficas asociada $\vec{s}$ con la fatiga en varios sujetos.

2. Este método fué aplicado en diez personas sanase 23 enfermos con rigidez matinal debida a la artritio̊ reumatoide y 21 enfermos con miopatía o con variał formas de neuropatía.

3. Las alteraciones eléctricas asociadas con la fatig son más acentuadas en enfermos reumáticos; se notaథ también en ciertos enfermos miopáticos pero son pocQ aparentes en los demás. 